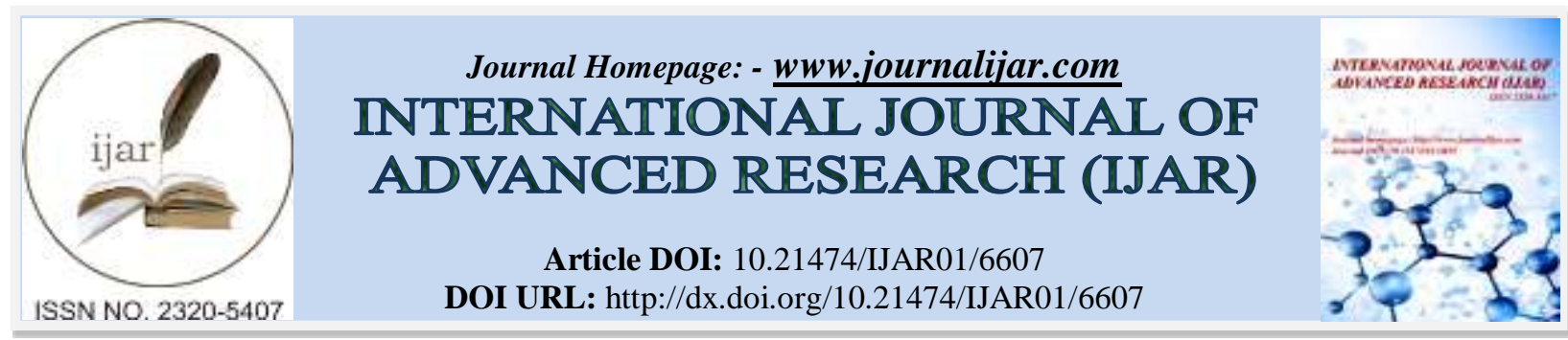

RESEARCH ARTICLE

\title{
A LEGAL ASPECT OF THE RETURN OF STATE FINANCIAL LOSSES BASED ON REPORT OF SUPREME AUDIT BOARD.
}

*Andri Yusuf, Muhammad Djafar Saidi, Syamsul Bachri and Aminuddin Ilmar.

Graduate School, Hasanuddin University, Makassar, Indonesia.

\section{Manuscript Info}

Manuscript History

Received: 22 December 2017

Final Accepted: 24 January 2018

Published: February 2018

Key words:-

Administration, Supreme Audit

Board, State Financial Losses.

\begin{abstract}
The settlement of State losses to the treasurer has important meaning in order to secure the State finances. As an effort to restore the State finances by obtaining indemnity suffered by the State, the settlement of losses against the treasurer can also be a lesson as well as the enforcement of the discipline and responsibility of the treasurer in the management of State finances. The research is empirical-normative legal research. The empirical aspect is a reality of the implementation of the examination recommendation of the Supreme Audit Board of the Republic of Indonesia in the case of the settlement of State losses against the treasurer. The results show that The implementation of the Supreme Audit Board' Recommendation in South Sulawesi Province cannot be done entirely for the achievement of good State financial management objectives. The recommendation of the Supreme Audit Board is corrective actions that must be followed-up for the achievement of orderly, lawful, efficient, economical, effective, transparent and accountable financial management by considers justice and properness. Legal steps that can be taken in order that the recommendation of the Supreme Audit Board in the South Sulawesi Province can have a forcing law force by strengthening the legal basis of the implementation of the recommendation of the Supreme Audit Board and cooperate with law enforcement officials authorized to conduct criminal prosecution if a rule has been violated.
\end{abstract}

Copy Right, IJAR, 2018,. All rights reserved.

\section{Introduction:-}

State finance as one of main elements in governance and plays an important role in realizing the goals of the State, as mandated in the opening of the 1945 Constitution. Therefore, State finances must be managed effectively, efficiently, transparently and in compliance with laws and regulations. To achieve such State financial management, it is necessary to have an objective and honest supervision from the internal and external government supervisors. Thus, if occurs deviation and leakage of State finances can be immediately known to be followed up (Karianga, 2016).

Any State losses should not be allowed to drag on too long without a settlement, as delays in the settlement may inhibit and complicate the recovery of State finances. According to Thompson (2000), in order to restore the State finances from losses, it is necessary to seek the settlement either through judicial institutions or outside the court.

Corresponding Author:- Andri Yusuf.

Address:- Graduate School, Hasanuddin University, Makassar, Indonesia. 
The settlement of State losses through the judiciary can be made against cases of State losses incurred as a result of criminal acts of corruption under the Criminal Code and against cases of breach of promise under the Civil Code. Settlement of State losses through institution outside the Court can be done through the settlement of State losses that are administrative based on the State administration.

Viewed from the State finance law which is a branch of State administrative law it is known that there are 2 (two) forms settlement of State losses to the treasurer previously known as the demands of the treasury and the settlement of State losses to non-treasurer/other officials known as the indemnity demands.

In the imposition of State financial indemnity to the treasurer set by the Supreme Audit Board, where if in the examination of regional losses found criminal elements, the Supreme Audit Board will follow-up in accordance with legislation. Another case with the imposition of regional indemnity against non-treasurer civil servants set by the head of the region.

The settlement of State losses to the treasurer has important meaning in order to secure the State finances. In addition as an effort to restore the State finances by obtaining indemnity suffered by the State, the settlement of losses against the treasurer can also be a lesson as well as the enforcement of the discipline and responsibility of the treasurer in the management of State finances.

Treasurer as an executive in the management of State finances has an important position and role since they are assigned to and on behalf of the State/region to receives, deposits, pays and/or deposits money or securities or State/ regional goods.

Treasurer' responsibility for the State financial losses in its management is the responsibility of the treasurer of cash shortage and it is better known as the treasury shortage. Therefore, as soon as the State losses are detected, the head of the state ministry/regional unit must conduct a prosecution and notification to the Supreme Audit Board.

It is less attention than the State financial losses caused by non-treasurer civil servant and third party and State losses caused by corruption. It can be seen from at least books, articles and other reading materials related to the settlement of State losses caused by the treasurer.

\section{2. Method OD THE RESEARCH}

The research is empirical-normative legal research (Soekanto et al., 2006). The empirical aspect is a reality of the implementation of the examination recommendation of the Supreme Audit Board of the Republic of Indonesia in the case of the settlement of State losses against the treasurer. The research was conducted in the area of South Sulawesi Province. Basic consideration of this research because South Sulawesi province as a research that has several districts whose financial loss return has been running but not yet effective and maximum in its settlement.

\section{3. ANALYSIS AND DISCUSSION}

3.1 Effectiveness of the Supreme Audit Board' Recommendation

The 1945 Constitution states, "to audit the management and responsibility about the State finances established a free and independent State Audit Board." It is as main basis for the implementation of the audit conducted by the Supreme Audit Board in relation to the State finance, it is also stated that further provisions concerning the Supreme Audit Board will be regulated by law. This provides delegation for the establishment of laws regulating the Supreme Audit Board while also providing legal standing for Supreme Audit Board as one of the state institutions (Saidi, 2011).

Audits as conducted by the Supreme Audit Board aimed to ensure that State finance is managed in an orderly, lawabiding, efficient, economical, effective, transparent and accountable manner with due regard to the sense of fairness and propriety. Audit result of the Supreme Audit Board are prepared after the audit is finished and it is conducted in the form of the audit report. However, if necessary, can arranging an audit interring report that regulated before the audit is completed for the purpose of immediate securing and/or to prevent extra-losses.

The response of the government official that responsible for the findings, conclusions and recommendations of the auditor is contained or attached to the audit result. This is important as a guide that the officer who responsible on entity has been aware of the audit results of the Supreme Audit Board. 
Audit result of the Supreme Audit Board as mentioned above also include the recommendation of the auditor, which is the recommendation of the auditor based on the audit result, sent to the person and/or authorized-agency to take action and/or improvement. The authorized-official shall be obliged to follow up on the recommendation of the auditor, while the Supreme Audit Board shall also monitor the follow-up actions of the entity and notify the results of follow-up to the representative body in the results of the semester audit.

Authorized-officials to and responsible for the management of state finances shall provide an answer or explanation to the Supreme Audit Board on the follow-up of the recommendations in the report of audit result submitted to the Supreme Audit Board no later than 60 (sixty) days after receipt of the report.

A form of force forces the implementation of a follow-up on the recommendation that is officials who are known not to perform the duty to follow up the recommendations may be subject to administrative sanctions in accordance with the provisions of legislation in the field of personnel. In addition administrative sanctions, there are also criminal sanctions that reinforce the need to implement follow-up on the recommendation of Supreme Audit Board with a maximum imprisonment of 1 (one) year 6 (six) months and/or a maximum fine of Rp. 500.000.000.00 (five hundred million rupiah).

Based on the audit report for indemnity of the Supreme Audit Board of the Republic of Indonesia on Semester II of 2016, the Supreme Audit Board has conducted the process of follow-up administering of State/Regional indemnity settlement to the treasurer in South Sulawesi Province, Maros, Bulukumba and Jeneponto as follows:

Table 1:- Total findings on Second II of 2016

\begin{tabular}{|l|l|l|}
\hline Name of Entities & Total Finding & Total finding (Rupiah) \\
\hline South Sulawesi Province & 1.268 & $130.867 .870 .234,97$ \\
\hline Maros & 910 & $82.657 .197 .852,15$ \\
\hline Bulukumba & 574 & $32.308 .963 .387,33$ \\
\hline Jeneponto & 823 & $55.510 .339 .389,69$ \\
\hline
\end{tabular}

Source: Monitoring report of State/Regional indemnity settlement on Semester II of 2016

A form of force forces the implementation of a follow-up on the recommendation that is officials who are known not to perform the duty to follow up the recommendations may be subject to administrative sanctions in accordance with the provisions of legislation in the field of personnel. In addition, administrative sanctions, there are also criminal sanctions that reinforce the need to implement follow-up on the recommendation of Supreme Audit Board with a maximum imprisonment of 1 (one) year 6 (six) months and/or a maximum fine of Rp. 500.000.000.00 (five hundred million rupiah).

The implementations of administrative and criminal sanctions against persons who do not fulfill the duty to follow up the recommendations submitted in the audit report have been based on laws and regulations but zero in its reality (Tjanra, 2006). Supervision as one of the basic functions of management is absolutely necessary in the State governance or State administration. From the beginning, the founders of the State did not ignore this is evidenced by the provision of the Supreme Audit Board in the 1945 Constitution (Zoelva, 2015). Although only limited to the field of State finances it can be said that the Supreme Audit Board is the organizer of supervisory functions in the State management system of the Republic of Indonesia whose position is outside the executive (government) as the object of supervision. Hence, auditing as conducted by the Supreme Audit Board is a form of supervision so that it should be followed both administratively and juridical.

Direct products of supervision are only in the form of data or information, final result or benefit of such supervision will only be visible or felt when the data and information has been utilized so as to give rise to concrete actions. Such actions are generally known as corrective action.

In an effort to enforce the supervisory function, follow-up supervision plays a very important role of supervision that not followed by follow-up supervision is not only a waste but more than that it will damage the image of the supervisory itself. The audit result of the Supreme Audit Board will only produce a pile of papers with audit report writing that become wasteful if the recommendations are not followed-up properly. 
The recommendation of the Supreme Audit Board as a corrective action against the audit findings as contained in the audit report of the Supreme Audit Board should be formulated by considers the implementation of follow-up action, since it is useless if the formulation of the recommendation of the Supreme Audit Board is impossible or difficult to implement by the entity. There needs to be good communication between the Supreme Audit Board and the entities examined in order to formulate recommendations that are appropriate and can be implemented by the entity concerned. Each entity certainly has different characteristics in terms of geography, human resources, work program, organizational structure and so forth. Thus, a similar recommendation may result in different follow-up achievements for different entities. The Supreme Audit Board auditor should be careful in providing appropriate recommendations for an entity.

\subsection{Legal Perspective of the Settlement of State Losses}

In order for securing and saving the States' wealth, necessary provisions regulating sanctions and prosecutions to anyone who because of the State for the settlement of the State losses. One party that can be prosecuted for the settlement of State losses is the treasurer.

By the presence of the State financial loss in the management of the treasurer and the loss is due to the act of violating the relevant treasurers' rule, then under the law there is a personal responsibility to recover the loss. Thus, the treasurer's personal property can be used to indemnify the State.

Responsibilities as mentioned above on the one hand raises the treasurers' obligation to indemnify the State financial losses and, on the other hand, rises the right of the agency's head where the treasurer works to require a sum of indemnity for losses suffered by the agency concerned. If the obligation is not immediately fulfilled, it can be analogized that against the State losses delayed, the treasurer is positioned as the debtor and the head of agency is positioned as creditor. Therefore, the head of agency may prosecute the treasurer.

The process of State loss imposition with the decision of imposition is done through 3 (three) stages: the issuance of Temporary Imposition Letter, Surat Keputusan Pembebanan Batas Waktu (SK PBW), and Imposition Letter of State Loss Indemnity. Temporary Imposition Letter contains the determination of temporary State indemnity imposition to the treasurer. Upon the issuance of the letter, the head of agency notifies it to the Supreme Audit Board.

Temporary Imposition Letter of State Losses has the legal power to seize the guarantee which its implementation is submitted by the relevant institution to the authorized institution for the seizure no later than 7 (seven) days after the issuance of Temporary Imposition Letter of State Losses under applicable laws and regulations.

Based on the provisions of Article 21 Paragraph (1) of Regulation of Supreme Audit Board of the Republic of Indonesia No. 3 of 2007, Temporary Imposition Letter of Head of Agency has the legal power to seize the guarantee (conservatoir beslag). This means that its legal force is equivalent or same to a court decision granting the petition of the parties in a civil suit lawsuit. Therefore, if this letter is executed consistently, it is actually quite effective as a means of settling the State losses.

In its implementation, the request for confiscation shall be submitted by the relevant institution to the authorized institution for the seizure not later than 7 (seven) days after the issuance of the temporary imposition letter. The implementation of guarantee confiscation is done in accordance with applicable laws and regulations.

Guarantee confiscation is the domain of civil procedure law that arises in a case or lawsuit. In this case, a guarantee of money or goods requested by the plaintiff to the court to ensure that the plaintiff's claim against the defendant can be executed if the court grants the claim. It is as regulated in the Het Herziene Idonesisch Reglement (HIR) or Reglemen Indonesia Baru (RIB), such as in Articles 178 to 227.

Guarantee confiscation means to guarantee the implementation of a decision in the future, the property of the defendant (or in the case of the treasurer), whether mobile or immobile goods, during the process takes place first confiscated (Winarno, (2010). The confiscated goods cannot be transferred, traded or transferred to others. If based on the judge' decision the plaintiff is won and the lawsuit is granted, the guarantee confiscation is automatically declared valid and valuable. Conversely, if stated defeated, the guarantee confiscation that has been placed will be ordered to be appointed. 
In essence, confiscation in guarantee confiscation is not intended to auction or sell the confiscated goods, but only be conserved by the court and may not be transferred or sold by the defendant. The issuance of Imposition Letter by the Supreme Audit Board shall be made in the event that the objection period has expired and the treasurer shall not file an objection. In addition, the Imposition Letter may also be issued in the event that the treasurer filed the objection is rejected by the Supreme Audit Board or in the event of State losses has not been fully replaced.

The decision of Supreme Audit Board on the Imposition of State Losses Indemnity contains the stipulation stating that the treasurer has been legally and convincingly proven to have made a mistake or negligence, causing the loss of the State in its management and obliging to indemnify the State by depositing it into the State/Regional cash (Forms of Imposition Decision can be seen on Attachment VI of the Supreme Audit Board Regulation No. 3 of 2007).

The Imposition Letter has legal force which is final, meaning that the letter has been legally binding and can be executed without any chance of appeal, besides it has precedence which is in civil law known as privilege (Article 1133 Civil Code). This precedence is the right to obtain pretenses given by the Act to obtain payment of a debt relative to other collectors.

Also, the Imposition Letter has the legal power to execute the execution confiscation (executorial beslag); execution as referred to in Article 196 of HIR. In this case, the execution to pay a sum of money equal to the State loss. If the treasurer is not willing to voluntarily pay the State losses (through SKTJM) then the guarantee confiscation that has been obtained under the provision of Imposition Letter will be changed into an execution confiscation with the issuance of the Imposition Letter.

The Imposition Letter submitted by the Supreme Audit Board to the treasurer through the direct superior of the treasurer or the head of the office with a copy to the head of the relevant institution with the receipt from the treasurer. Within a period of 7 (seven) days from receipt of the imposition letter, the treasurer shall execute in the form of paying a loss to the State/Region.

In the event that the treasurer has indemnified the State losses in cash, the confiscated property is returned to the person concerned (Tuanakotta, 2009). If the specified time period has been exceeded and the treasurer shall not indemnify the State losses in cash, the concerned agency shall file a request to the competent authority to confiscate and sell the auction on the treasurer's property. During the auction process, deduction of the income received by the treasurer by $50 \%$ (fifty percent) from every month until it is paid off.

If the treasurer does not own the property for sale or the proceeds of the sale are insufficient for the indemnify of State losses, the head of agency concerned shall seek the State loss of return through the withholding of at least 50\% (fifty percent) of the monthly earnings to full payment. Whereas if the treasurer enters retirement, then in SKPP stated that the concerned still has debts to the State and retirement saving which is the right of treasurer can be calculated to indemnify the State losses.

As discussions on the mechanism of settlement of State losses against the treasurer as described above, it can be seen that there are differences and similarities in the mechanism of settlement of State losses against the treasurer before and when the enactment of the Supreme Audit Board Regulation No. 3 of 2007 as follows:

(a) Both are recognized the settlement of the States losses against the treasurer peacefully through an absolute liability letter. Prior to the enactment of Supreme Audit Agency Regulation No. 3 of 2007 and the State Financial Package Act abbreviated SKTJM made by government agencies and the period of implementation was two years. With the enactment of Supreme Audit Agency Regulation No. 3 of 2007 and the State Financial Package Act abbreviated to SKTJM made by and as statement of treasurer with the period of its implementation is 40 days.

(b) Previously, the settlement of State losses against the treasurer distinguished between the settlement by peace and the settlement by treasury prosecution, the settlement by peace shall be made by the government agency while the treasury prosecution shall be made by the Supreme Audit Board. Now, the settlement is not distinguished between a settlement by peace and by treasury prosecution. All of them constitute a unity of States losses settlement against the treasurer as conducted by the head of agency. While, the Supreme Audit Board is no longer authorized to prosecute, but to provide determination/imposition through the Decision Letter of the Supreme Audit Board. 
(c) Both are recognized the temporary imposition issued by the head of agency. Previously, it known as Temporary Imposition Letter with the issuance of this letter can be deducted from the concerned income. Now, it is known as Temporary Imposition Letter serves to establish losses prior to the issuance of the determination of the Supreme Audit Board through the Imposition Letter. With the issuance of this letter, it can only guarantee confiscation without any authority to deduct the treasurer's income. New income deductions are made in case of auction process.

(d) Both are recognized the term of the time limit provision which gives the treasurer an opportunity to file an objection within 14 (fourteen) days. Previously, this letter was known as SK Penetapan Batas Waktu (SK PBW).

(e) Through the treasury prosecution, there are first-level prosecution and appeals while now only the imposition letter as first and final decision.

State losses due to unlawful act of treating the treasurer either intentionally or negligently need to be settled immediately because if it is allowed, it can cause the States' finances to become unhealthy which affects the hampering of government administration. In addition, the obligation to settle the States losses by the treasurer is a juridical consequence of the treasurer's liability in the management of the money or goods entrusted to him/her.

Here, the liability means that the treasurer is entrusted to administer or manage money or goods by receiving, keeping, paying to hand over and administering and accounting for money or securities or State/Region goods.

The manifestation of its management liability is reflected in the obligation of the treasurer to submit the liability report to the Supreme Audit Board and to be personally liable for the financial losses of the State in its management. With the obligation to indemnify for losses incurred due to unlawful act of treasurer either intentionally or due to negligence, then in the execution of its duties it is expected that the treasurer will be careful in carrying out its duties in accordance with the applicable provisions.

Increased liability of the treasurer in the management of State finances may also be made by the imposition of sanctions as regulated in Article 38 of the Supreme Audit Board Regulation No. 3 of 2007 stating that against the treasurer who has been appointed to indemnify the State may be subject to administrative sanctions and/or criminal sanctions in accordance with the provisions prevailing laws and regulations.

Basically, the provisions of the procedure for settlement of State losses against the treasurer as stipulated in the Supreme Audit Board Regulation No. 3 of 2007 is quite strict in the context of the settlement of the State losses against the treasurer. The procedure for settlement of State losses against the treasurer provides alternatives to settlement of State losses against the treasurer. For example, in the case that the treasurer has made and holds accountable then the accountability for the State losses is levied on him/her. Further, in the case that the treasurer does not hold accountable, the calculation shall be executed ex officio and his/her liability shall be transferred to the heirs/beneficiaries or other parties who have the right but only limited to the managed or obtained wealth derived from the treasurer.

The procedure for settlement of State losses against the treasurer also provides the provisions of the time period so that the settlement time can already be measured. This procedure also allows the settlement of losses of the State/ region with the withholding of the income received by the treasurer by $50 \%$ (fifty percent) of each month until it is paid off.

If the treasurer does not own the property for sale or the proceeds of sale are insufficient for the indemnify of State losses, the head of agency concerned shall seek the return of the State through a minimum cut of $50 \%$ (fifty percent) of each month until it is paid off.

Based on the example of arrangement the settlement of State losses against the treasurer as mentioned above, there should be certainty that the losses of the State/Region which occurred due to the mistake/negligence of the treasurer can be settled (Ridwan, 2013). In order to know the loss of the State/region that occurred and the progress of its settlement, the Supreme Audit Board is entitled to receive reports from the existing agencies.

In the event of a loss of a State/region, Article 60 Paragraph (1) and Article 61 Paragraph (1) of Act No. 1 of 2004 requires the direct superior or the head of the office or the head of the regional apparatus unit to report the loss to the 
minister/head of the institution or head region and notify it to the Supreme Audit Board no later than 7 (seven) working days after the loss is known. Based on the results of the Supreme Audit Board audit can also be found the loss of the State/region caused by the negligence of the treasurer.

These findings indicate that the State losses to be liable to the treasurer are still encountered in the practice of State financial management. Based on Act No. 1 of 2004 and Act No. 15 of 2004, the loss must be settled by the head of the institution where the treasurer works. Further arrangement on the settlement of State losses against the treasurer shall be regulated in the Supreme Audit Board Regulation No. 3 of 2007. The provisions contained in the regulation shall be used as guidance for the head of the agency to settle the State losses to the treasurer.

Based on Article 23 of Act No. 15 of 2004, the head of institution shall report the settlement of the loss of State/region to the Supreme Audit Board no later than 60 (sixty) days after the loss of the State/region is known. This is related to the authority of the Supreme Audit Board as a free and independent financial auditing board to secure State finances by continuously monitoring the losses of the State. This authority is stipulated in Article 10 Paragraph (3) which states that in order to guarantee the implementation of indemnity payments, the Supreme Audit Board is authorized to monitor the implementation of the imposition of loss of State/Region to the treasurer, the management of State-Owned Corporation/Region-Owned Corporation, and other institutions or bodies that managing State finances as stated by the Supreme Audit Board.

This happens because the government agencies have not implemented the Supreme Audit Board No. 3 of 2007. The indication is reflected from the monitoring results of the Supreme Audit Board that found that the State losses have not yet completed. In addition, the implementation of indemnity execution of the State/region and the lack of coordination of central/regional government agencies with the relevant agencies, that is the Directorate General of State Assets. Other causes are loss of State/Region which still in the form of findings from the audit result of the Supreme Audit Board and from apparatus of internal control of government have not been followed-up quickly in mechanism of settlement of State losses as stipulated in the provisions of the Supreme Audit Board Regulation No. 3 of 2007.

\section{Conclusion:-}

The implementation of the Supreme Audit Board' Recommendation in South Sulawesi Province cannot be done entirely for the achievement of good State financial management objectives. The recommendation of the Supreme Audit Board is corrective actions that must be followed-up for the achievement of orderly, lawful, efficient, economical, effective, transparent and accountable financial management by considers justice and properness. Legal steps that can be taken in order that the recommendation of the Supreme Audit Board in the South Sulawesi Province can have a forcing law force by strengthening the legal basis of the implementation of the recommendation of the Supreme Audit Board and cooperate with law enforcement officials authorized to conduct criminal prosecution if a rule has been violated.

Actually, the existing legislation has given sufficient sanction to encourage the follow-up of Supreme Audit Board audit results. However, the legislation has not been fully implemented so that the settlement of State losses against the treasurer is not yet optimal. Such indications are reflected in the execution of the indemnity of the State/Region based on the determination of the Supreme Audit Board has not been implemented optimally by the central/regional government agencies. 


\section{References:-}

1. Karianga, H. (2016). New Paradigm for Local Financial Management: A Review of Local Budgeting System. Hasanuddin Law Review, 2(3), 398-408. doi: http://dx.doi.org/10.20956/halrev.v2i3.700

2. Ridwan. (2013). Diskresi dan Tanggung Jawab Pejabat Dalam Penyelenggaraan Pemerintahan di Indonesia. (Dissertation). Surabaya: Universitas Airlangga.

3. Saidi, M.D. (2011). Hukum Keuangan Negara. Revision edition. Jakarta: PT. RajaGrafindo Persada.

4. Soekanto, S. and Mamudji, S. (2006). Penelitian Hukum Normatif, Suatu Tinjauan Singkat. Jakarta: PT Raja Grafindo Persada.

5. Thompson, D. F. (2000). Political Ethics and Public Office. Translated by Benyamin Molan. Jakarta: Yayasan Obor Indonesia.

6. Tjanra, W.R. (2006), Hukum Keuangan Negara, Jakarta: Gramedia Widiasaran Indonesia.

7. Tuanakotta, T.M. (2009). Menghitung Kerugian Keuangan Negara dalam Tindak Pidana Korupsi. Jakarta: Salemba Empat Publisher.

8. Winarno, N.B. (2010). Penyalahgunaan Wewenang Dalam Pengelolaan Keuangan Daerah. Yogyakarta: Lasbang Mediatama.

9. Zoelva, H. (2015). Prospek Negara Hukum Indonesia: Gagasan dan Realita. Hasanuddin Law Review, 1(2), 178-193. doi: http://dx.doi.org/10.20956/halrev.v1n2.78 